\title{
Spontaneous intracranial hypotension presenting with coma: a case report and literature review
}

\author{
Koma ile prezente olan spontan intrakraniyal hipotansiyon: \\ Olgu sunumu ve literatürün gözden geçirilmesi
}

\author{
Yahya ÇELIK,' Aslan TEKATAŞ, ${ }^{1}$ Sait ALBAYRAM, ${ }^{2}$ \\ Ayşegül GÜNDÜZ, ${ }^{3}$ Talip ASIL,, ${ }^{4}$ Ercüment ÜNLÜ, ${ }^{5}$ Hatice ÖZLECE KÖSE ${ }^{6}$
}

\begin{abstract}
Summary
Spontaneous intracranial hypotension is characterized by orthostatic headache in the absence of a history of head trauma or lumbar puncture, and diagnosis is confirmed by a specific cerebrospinal fluid pressure and neuroimaging findings. It rarely presents with coma. A 62-year-old man presented with progressive cognitive decline of 2 to 4 weeks' duration. He was diagnosed with spontaneous intracranial hypotension according to cerebrospinal fluid pressure and neuroimaging findings, and treated conservatively.
\end{abstract}

Key words: Coma; spontaneous intracranial hypotension.

\begin{abstract}
Özet
Spontan intrakraniyal hipotansiyon (SiH) kafa travması ve lomber ponksiyon öyküsü olmaksızın ortastatik başağrısı, beyin omurilik sıvısı (BOS) basınç değişikliği ve sinir sistemi görüntülemesi ile karakterize bir tablodur. Altmış iki yaşında iki-dört hafta içinde ilerleyici kognitif yıkımla prezente olan erkek hastaya BOS basıncı ve sinir sistemi görüntülemesi sonuçlarına gore $\mathrm{SiH}$ tanısı konuldu ve konservatif olarak tedavisi yapıldı. Spontan intrakraniyal hipotansiyon oldukça nadir olarak koma ile de prezente olabilir.
\end{abstract}

Anahtar Kelimeler: Koma; spontan intrakraniyal hipotansiyon.

\section{Introduction}

Spontaneous intracranial hypotension $(\mathrm{SIH})$ is increasingly attracting attention because it is reported to cause various symptoms in a spectrum from orthostatic headache to coma and it may lead to fatal complications. In addition to postural headache, other common clinical presentations include neck pain and nausea that sometimes may be orthostatic, unilateral or bilateral sixth cranial nerve palsy, dizziness, hearing problems, visual blurring, photophobia, visual field defect, interscapular pain, low back pain, and radicular upper limb symptoms. Much less frequent or rare manifestations are facial numbness or weakness, galactorrhea, neurogenic bladder, coma, third and fourth cranial nerve palsies, chorea, Parkinsonism and ataxia, fronto-temporal dementia, encephalopathy, cervical radiculopathy, and labyrinthine hydrops. ${ }^{[1]}$ This variability of symptoms also brings a disadvantage in making the diagnosis. So, neuroimaging investigations play an important role in diagnosis and when the clinical presentation is mental confusion or coma, reported findings are dif-

\footnotetext{
'Department of Neurology, Trakya University Faculty of Medicine, Edirne, Turkey

2Department of Radiology, Istanbul University Cerrahpasa Faculty of Medicine, Istanbul, Turkey

${ }^{3}$ Department of Neurology, Istanbul University Cerrahpasa Faculty of Medicine, Istanbul, Turkey

${ }^{4}$ Department of Neurology, Bezmialem Vakif University Faculty of Medicine, Istanbul, Turkey

${ }^{5}$ Department of Radiology, Trakya University Faculty of Medicine, Edirne, Turkey

${ }^{6}$ Department of Neurology, Kafkas University Faculty of Medicine, Kars, Turkey

Submitted: 06.08.2013 Accepted after revision: 17.03.2014
}

Correspondence: Dr. Yahya Çelik. Trakya Üniversitesi Tıp Fakültesi, Nöroloji Anabilim Dalı, Edirne, Turkey.

Tel: +90 - 284 - 2357641 / 4510 e-mail: celikyahyatr@yahoo.com

(c) 2015 Turkish Society of Algology 

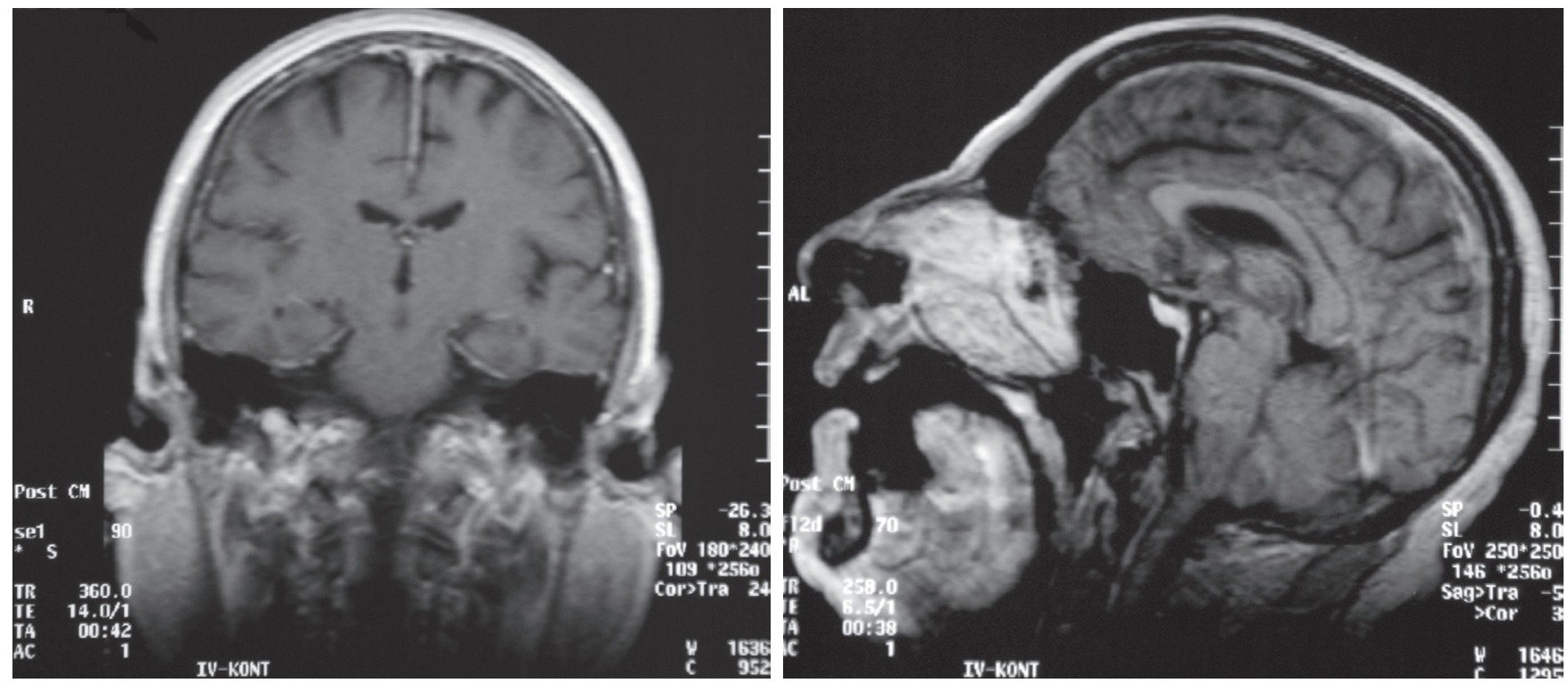

Figure 1.MRI scans showing diffuse pachymeningeal contrast enhancement and mild compression of brainstem.

fuse subdural fluid collections and/or hematoma, cerebral edema, descent of cerebral tonsils and diffuse enhancement of pachymeninges which is relatively specific. Severe displacement of the brain or diencephalic edema may be responsible for decreased level of consciousness.

Since treatment with epidural interventions reverses the clinical status even in comatose patients, $\mathrm{SIH}$ should be considered in the differential diagnosis of stupor and coma. Here, we describe a patient admitted with orthostatic headache and progressed to coma in a short period who was diagnosed as $\mathrm{SIH}$ and improved completely after conservative treatment and review $\mathrm{SIH}$ cases presented with decreased level of conciousness in the literature.

\section{Case Report}

A 62-year-old man presented with a progressive cognitive decline of 2 to 4 weeks' duration. He was well until approximately 1 month before admission when he developed diffuse headache that typically worsened when he was in upright or sitting position and was relieved when he was supine. There was no history of known malignancy, head trauma, fevers, CSF rhinorrhea or otorrhea.

On examination, the patient was clearly obtunded with his eyes opened only on vigorous voice stimulation accompanied by gentle shaking. Verbal output was slow, dysarthric, and limited to one-or two-word responses. Simple commands were obeyed at times with repetitive stimulation. Initial Glascow coma scale (GCS) score was 11 (E2, M5, V4) with bilateral positive Babinski's response. Cranial nerve and motor examinations were unremarkable. Reflexes were mildly brisk. Computed tomography (CT) scanning and electroencephalography studies were normal. However, since magnetic resonance imaging (MRI) showed diffuse pachymeningeal contrast enhancement and mild compression of brainstem without subdural effusion (Figure 1) and history revealed orthostatic headaches, he underwent lumbar puncture which showed an opening pressure of $9.5 \mathrm{~cm}$ $\mathrm{H}_{2} \mathrm{O}$, leukocyte count $5 / \mathrm{mm}^{3}$ and normal protein and glucose levels. The neuroimaging and cerebrospinal findings supported the diagnosis of SIH. During those investigations, his clinical status deteriorated, GCS score became 7, he was intubated and transferred to intensive care unit. Despite the clinical deterioration neuroimaging findings were stabile and firstly he was treated with conservative management, including bed rest in trandelenburg position and fluid administration. After lying flat for $24 \mathrm{~h}$ his cognitive state improved, he was awake and extubated. This treatment continued for 2 weeks until when he was stabilized and had no symptoms.

\section{Discussion}

Orthostatic hypotension may be a postoperative complication after neurosurgery or may develop spontaneously. Although it is a rare complication of 
neurosurgery, we think that $\mathrm{SIH}$ is underdiagnosed since there are various clinical and radiological findings. Decrease of mental status ranging from confusion to coma is reported in few patients which is making the diagnosis even more difficult. In those patients orthostatic headache generally preceded above-mentioned clinical finding $\mathrm{s}^{[2-4]}$ and from the clinical point of view this may be the most important clue for the diagnosis. In the case of decreased CSF volume, third nerve paresis and anisocoria may even accompany and complicate the clinical picture indicating mass lesion. ${ }^{[5]}$ Radiological features in cases with coma are subdural fluid collections/ hematoma, increasingly attenuated basilar cisterns, cerebral edema, diffuse enhancement of meninges and downward displacement of diencephalon and cerebellar tonsils. ${ }^{[6-9]}$ According to Monro-Kellie hypothesis decreased cerebrospinal fluid pressure results in venous congestion resulting in enhancement of meninges or subdural collection which may cause herniation and mental decline. However, Savoiardo et al. ${ }^{[10]}$ reported increased diffusivity in diencephalo-mesencehalic structures by MRI in patients with brain sagging which is suggested to reflect vasogenic edema in those deep structures. Although authors reported somnolance in one patient, neurological examination revealed ideomotor slowing in 3 of 5 patients. Therefore, edema of such a place which is important in maintenance of alertness may be responsible for changes of conciousness in $\mathrm{SIH} \mathrm{pa-}$ tients. However, in our patient although there were no subdural collections or herniations, mild compression of brainstem was observed as a result of venous congestion and following downward displacement of brain which may cause cognitive decline.

Choice of treatment is application of epidural blood patch (EBP) even in the presence of subdural hematomas and it improves the clinical symptoms in 24 hours. ${ }^{[2,7,8]}$ Although evacuation of subdural collections provides transient improvements, this effect is not persistent. In few cases where EBP did not benefit epidural interventions like fibrin glue enjection ${ }^{[6]}$ or saline infusion ${ }^{[3]}$ reversed symptoms. This shows epidural interventions are effective and safe in the treatment of $\mathrm{SIH}$ in comatose patients even in the presence of subdural hematomas and tonsillar her- niation. However, we preferred conservative treatment in the first step because although we observed clinical deterioration, neuroimaging findings were stabile and he had an opportunity to improve with only conservative treatment. Clinical outcome also supported our opinion.

In conclusion, in the setting of mental decline orthostatic headache should be asked and in any suspicious case MRI with gadolinium should be performed since early recognition is crucial. Although EBP may be a life saving procedure in those cases, improvement with conservative treatment is also possible.

\section{Conflict-of-interest issues regarding the authorship or article: None declared.}

\section{Peer-rewiew: Externally peer-reviewed.}

\section{References}

1. Mokri B. Cerebrospinal fluid volume depletion and its emerging clinical/imaging syndromes. Neurosurg Focus 2000;9(1):e6.

2. Whiteley W, Al-Shahi R, Myles L, Lueck CJ. Spontaneous intracranial hypotension causing confusion and coma: a headache for the neurologist and the neurosurgeon. $\mathrm{Br} J$ Neurosurg 2003;17(5):456-8.

3. Binder DK, Dillon WP, Fishman RA, Schmidt MH. Intrathecal saline infusion in the treatment of obtundation associated with spontaneous intracranial hypotension: technical case report. Neurosurgery 2002;51(3):830-7.

4. Kashmere JL, Jacka MJ, Emery D, Gross DW. Reversible coma: a rare presentation of spontaneous intracranial hypotension. Can J Neurol Sci 2004;31(4):565-8.

5. Mathew L, Komotar R. Epidural blood patch for severe postoperative intracranial hypotension. J Neurosurg Anesthesiol 2008;20(1):49-52.

6. Schievink WI, Moser FG, Pikul BK. Reversal of coma with an injection of glue. Lancet 2007;369(9570):1402.

7. Sayer FT, Bodelsson M, Larsson EM, Romner B. Spontaneous intracranial hypotension resulting in coma: case report. Neurosurgery 2006;59(1):E204.

8. Shrikrishna D, Green C, Wood D, Handel J. Life-threatening spontaneous intracranial hypotension responding to epidural blood patch. Br J Anaesth 2006;97(5):750.

9. Kremer S, Taillandier L, Schmitt E, Bologna S, Moret C, Picard $\mathrm{L}$, et al. Atypical clinical presentation of intracranial hypotension: coma. J Neurol 2005;252(11):1399-400.

10. Savoiardo M, Minati L, Farina L, De Simone T, Aquino D, Mea $E$, et al. Spontaneous intracranial hypotension with deep brain swelling. Brain 2007;130(Pt 7):1884-93. 